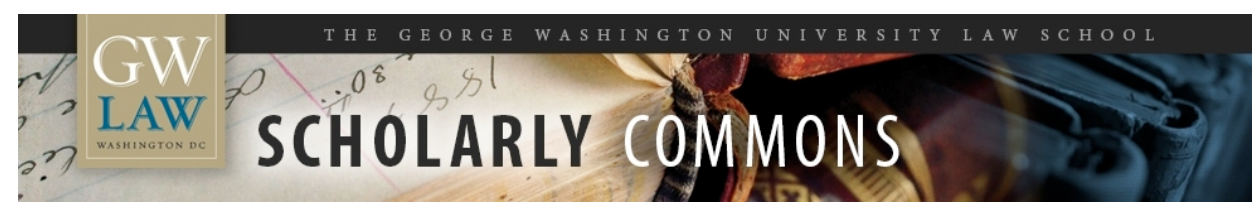

\title{
Supreme Court Brief Amicus Curiae of Administrative Law Scholars in Support of Neither Party
}

\author{
Richard J. Pierce Jr \\ George Washington University Law School, rpierce@law.gwu.edu \\ Robert L. Glicksman \\ George Washington University Law School, rglicksman@law.gwu.edu \\ Emily Hammond \\ George Washington University Law School \\ Alan B. Morrison \\ George Washington University Law School, abmorrison@law.gwu.edu \\ Jonathan R. Siegel \\ George Washington University Law School, jsiegel@law.gwu.edu
}

Follow this and additional works at: https://scholarship.law.gwu.edu/faculty_publications

Part of the Law Commons

\section{Recommended Citation}

Pierce, Richard J. and Glicksman, Robert L. and Hammond, Emily and Morrison, Alan B. and Siegel, Jonathan R., Supreme Court Brief Amicus Curiae of Administrative Law Scholars in Support of Neither Party (2018). GWU Law School Public Law Research Paper No. 2018-07; GWU Legal Studies Research Paper No. 2018-07. Available at SSRN: https://ssrn.com/abstract=3135528

This Brief is brought to you for free and open access by the Faculty Scholarship at Scholarly Commons. It has been accepted for inclusion in GW Law Faculty Publications \& Other Works by an authorized administrator of Scholarly Commons. For more information, please contact spagel@law.gwu.edu. 
No. 17-130

IN THE

\section{Supreme Court of the finited States}

RAYMOND J. LUCIA, ET AL.,

PETITIONERS,

v.

SECURITIES \& EXCHANGE COMMISSION, RESPONDENT.

On Writ of Certiorari to the

United States Court of Appeals for the D.C. Circuit

BRIEF AMICUS CURIAE OF ADMINISTRATIVE LAW SCHOLARS IN SUPPORT OF NEITHER PARTY

RICHARD J. PIERCE, JR.

COUNSEL OF RECORD

ROBERT GLICKSMAN

EMILY HAMMOND

ALAN B. MORRISON

JONATHAN R. SIEGEL

THE GEORGE WASHINGTON

UNIVERSITY LAW SCHOOL 2000 H STREET NW

Washington, DC 20052

(703) 304-1623

February 28, 2018

rpierce@law.gwu.edu 
TABLE OF CONTENTS

TABLE OF AUTHORITIES ................................. ii

INTEREST OF AMICI CURIAE .......................... 1

INTRODUCTION …........................................ 1

SUMMARY OF ARGUMENT ............................... 3

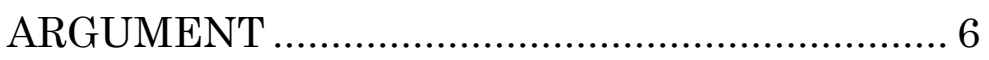

I. THE METHOD OF APPOINTING ALJS AND THE STATUTORY LIMITS ON MANAGEMENT AND REMOVAL OF ALJS HAS A RICH HISTORY................................... 6

A. CONGRESS DEVOTED MUCH OF THE 1930s AND 1940s TO DESIGNING A STRUCTURE IN WHICH ALJS HAVE AN APPROPRIATE DEGREE OF DECISIONAL INDEPENDENCE. 6

B. THIS COURT ISSUED A SERIES OF DECISIONS IN THE 1950s IN WHICH IT ENDORSED THE LEGAL REGIME GOVERNING ALJS THAT CONGRESS CREATED.

II. ANY CHANGE IN THE STATUS OF ALJS SHOULD BE CONSISTENT WITH THE OVERRIDING GOAL OF MINIMIZING THE RISK OF PRO-AGENCY BIAS...................... 17

CONCLUSION ............................................... 21 ADDENDUM: LIST OF PARTICPATING SCHOLARS Add. 1 


\section{TABLE OF AUTHORITIES}

\section{Cases}

Bandimere v. SEC, 844 F.3d 1168, rehearing en banc denied, 855 F.3d 1128 (10 ${ }^{\text {th }}$ Cir. 2016) ...... 3

Bowsher v. Synar, 478 U.S. 714 (1986) ................ 21

Cates v. Haderlein, 342 U.S. 804 (1952) .............. 16

FEC v. NRA Political Victory Fund, 513 U.S. 88 (1994).

FEC v. NRA Political Victory Fund, 6 F. 3d 821

(D.C. Cir. 1993)

Free Enterprise Fund v. Public Company

Accounting Oversight Board, 561 U.S. 477 (2010). 18,20

Marcello v. Bonds, 349 U.S. 302 (1955) 16,17

Ramspeck v. Federal Trial Examiners Conference, 345 U.S. 128 (1953)..................................passim

Raymond J. Lucia Cos. v. SEC, 832 F.3d 277 (D.C. Cir. 2016), rehearing en banc denied, 868 F.3d 1021 (2017)................................................ 3

Riss \& Co. v. U.S., 341 U.S. 907 (1951) ............... 16

Universal Camera v. NLRB, 340 U.S. 474 (1951).....

Wong Yang Sung v. McGrath, 339 U.S. 33 (1950).... $14,15,16$

Statutes and Regulations

17 C.F.R. § $201.410 \ldots \ldots \ldots \ldots \ldots \ldots \ldots \ldots \ldots \ldots \ldots \ldots \ldots \ldots \ldots \ldots \ldots . . . .22$

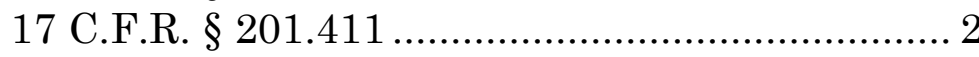

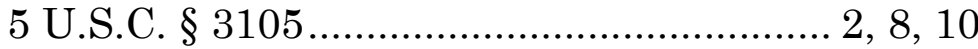

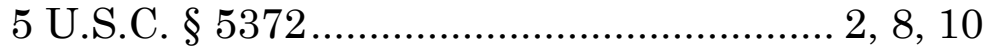

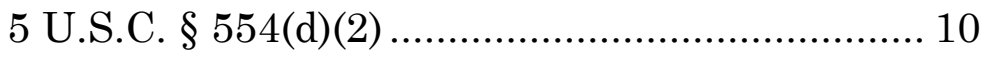

5 U.S.C. $\S 557(b)$........................................ 2, 11 


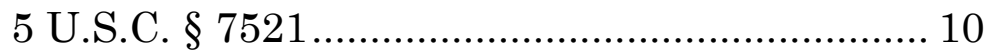

Pub. L. No. 111-203, 124 Stat. 1376 (2010) ........ 18

Pub. L. No. 95-251, 92 Stat. 183 (1978) ................. 9

\section{Miscellaneous}

Change of Title to Administrative Law Judge, 37

Fed. Reg. 16,787 (Aug. 19, 1972)....................... 9

George Shepherd, Fierce Compromise: The Administrative Procedure Act Emerges from New Deal Politics, 90 N.W. U. L. Rev. 1557 (1996)

Paul Verkuil et al., The Federal Administrative Judiciary, Admin. Conf. of the United States, Recommendations and Reports Vol II, pp. 7701139 (1992), https://www.acus.gov/sites/default/files/documen ts/19922\%20ACUS\%20\%28Green\%20Book\%29.pdf ..... 7

SEC Order, re: Pending Administrative Proceedings (Nov. 30, 2017) ............................... 3

U.S. OPM, ALJs by Agency (Mar. 2017), https://www.opm.gov/services-foragencies/adminstrative-law-judges/\#url=ALJsby-Agency ..................................................... 17

Urska Velikonja, Are the SEC's Administrative Law Judges Biased? An Empirical Investigation, 92 Wash. L. Rev. 315 (2017) ..... 18 


\section{INTEREST OF AMICI CURIAE' ${ }^{1}$}

The individuals who have agreed to participate in this brief are 29 law professors who teach and write about administrative law. They have no interest in these cases or the parties except in their capacities as teachers and scholars. Their names and affiliations appear in an Addendum to this brief. They are filing this brief in support of neither party in order to call the Court's attention to pragmatic considerations of which the Court should be aware in deciding the question presented. Some of the amici believe that Administrative Law Judges (ALJs) are inferior officers, while others believe that they are properly treated as employees. All of us agree that, whatever the Court's conclusion, the result must continue to protect the independence of ALJs, consistent with the goal of the Administrative Procedure Act which created their positions.

\section{INTRODUCTION}

After presiding at a hearing, an ALJ employed by the Securities \& Exchange Commission (SEC) wrote an Initial Decision in which he determined that petitioners Raymond J. Lucia et al. (Lucia) violated statutes implemented by the SEC. Lucia exercised its right pursuant to

\footnotetext{
${ }^{1}$ This brief is filed pursuant to consents obtained from all parties. No person other than amici and their counsel have authored this brief in whole or in part or made a monetary contribution toward its preparation or submission.
} 
SEC rules to obtain de novo review of that decision. 17 C.F.R. § 201.410, 201.411. The SEC conducted "an independent review of the record, except with respect to those findings not challenged on review." Pet. App. 40a. The SEC exercised the power conferred on it by the Administrative Procedure Act (APA): "On appeal from or review of the initial decision, the agency has all the powers it would have in making the initial decision." 5 U.S.C. § 557(b). In its opinion, the SEC agreed with the ALJ with respect to most but not all issues. Two Commissioners dissented with respect to one issue. Lucia sought review of the SEC decision in the D.C. Circuit. Lucia argued, inter alia, that the SEC's decision was invalid because the ALJ who presided in the hearing was an inferior officer who was not appointed in a manner consistent with the Appointments Clause. Instead, the SEC had appointed the ALJ in a manner consistent with the APA. 5 U.S.C. § 3105 provides that "each agency" that employs ALJs "shall appoint" the ALJs who work for the agency. 5 U.S.C. $\S 5372$ provides that the Office of Personnel Management (OPM) "shall by regulation prescribe . . the qualifications to be required for appointment [of ALJs]." Acting under authority delegated by the SEC, the Chief ALJ at the SEC appointed the ALJ who presided in this case. That ALJ had previously been determined by OPM to be qualified to be an ALJ.

A panel of the D.C. Circuit Court of Appeals upheld the SEC decision on the basis of its conclusion that SEC ALJs are employees rather than inferior officers because their decisions at the conclusion of a hearing are only recommendations that the SEC is free to accept or reject. Raymond $J$. 
Lucia Cos. v. SEC, 832 F.3d 277 (D.C. Cir. 2016), rehearing en banc denied, 868 F.3d 1021 (2017).

Before the Court granted the writ of certiorari in this case, the Solicitor General filed a brief in which he announced that the government had changed its position and now believes that ALJs are inferior officers who can only be appointed by Heads of Departments. The government expressed its agreement with the opinion of the Tenth Circuit in Bandimere v. SEC, 844 F.3d 1168, rehearing en banc denied, 855 F.3d 1128 (10 th Cir. 2016). The Tenth Circuit held that SEC ALJs are inferior officers even though they lack the power to make final decisions because their positions, including their "duties, salary, and means of appointment," are established by statute and because they exercise significant discretion in carrying out important quasi-judicial functions.

The SEC responded to this change in the government's position the next day by issuing an order in which it ratified the appointments of ALJs that had previously been made by its Chief ALJ and ordered its ALJs to reconsider the actions they had taken in pending proceedings in their new capacity as appointees of the head of the agency. Order, In re: Pending Administrative Proceedings (Nov. 30, 2017).

\section{SUMMARY OF ARGUMENT}

The history of ALJs-and in particular, the importance of their independence within agencies, sheds important light on this case. Amici respectfully urge this Court to evaluate this case in light of the congressional purpose of ensuring the 
independence and neutrality of ALJs. These features, in turn, protect the property and liberty interests at stake in agency adjudications and, ultimately, act as checks on agency power.

Congress devoted a substantial amount of time during the 1930s and 1940s to the question of how to structure agencies that engage in adjudication of regulatory disputes. That debate resulted in unanimous enactment of the Administrative Procedure Act (APA) in 1946. One of the core features of the APA was a complicated set of statutory safeguards to assure that the hearing examiners (later renamed ALJs) who were to preside over most agency hearings did not act in ways that reflected bias in favor of the agency that employed them. Congress created a multi-step process for appointing hearing examiners and imposed statutory limits on the power of agencies to manage and remove hearing examiners that were specifically designed to ensure that they had an appropriate degree of decisional independence from the agencies whose cases they were to hear.

This Court issued three opinions during the period from 1950 to 1955 in which it (1) acknowledged with obvious approval the congressional decision to create the position of hearing examiner with a degree of decisional independence from the agencies whose cases they adjudicate, (2) encouraged Congress to use independent hearing examiners to preside in all agency hearings, and (3) upheld the initial rules the Civil Service Commission (later renamed the Office of Personnel Management) issued to implement the provisions of the APA that were intended to assure that hearing examiners have an 
appropriate degree of decisional independence from the agencies at which they preside.

This case was initiated in response to the SEC's use of the discretion Congress conferred on it in the Dodd-Frank Act to use its ALJs to preside in hearings in some types of enforcement proceedings. Previously, such cases were subject to adjudication exclusively in federal district courts. The shift of some enforcement cases from federal courts to the SEC gave rise to complaints that SEC ALJs were unduly biased in favor of the SEC. Ironically, to the extent that pro-agency bias is a concern, changing the status of ALJs as urged by petitioner would give the agency greater control over ALJ-precisely the outcome that Lucia purports to disavow.

The Court's holding and approach in this case have major implications for the adjudicative structure of the federal government. If the Court were to apply the Tenth Circuit test to the five SEC ALJs as the basis for a holding that they are inferior officers, federal courts would be required to apply the same test to the $1,926 \mathrm{ALJs}$ who perform analogous functions at other agencies. And it would almost certainly trigger similar challenges to decisions made by the thousands of non-ALJ adjudicators (often referred to as administrative judges or AJs) who perform analogous functions at other agencies. Together, ALJs and AJs preside at hearings in millions of adjudications each year.

If, as seems likely, that iterative process yielded a series of holdings that many thousand federal employees with responsibilities that include presiding at hearings are inferior officers, federal courts would then have to decide what to do 
about the cases that have been the subject of hearings presided over by those unconstitutionally appointed officers. Courts would also have to decide whether the statutory restrictions on removal of the members of this large new class of inferior officers are constitutional, an issue not before the Court in this case. The point, however, is that the stakes are sufficiently high to justify a judicial approach that preserves as much as possible the congressional design to check agency power through the use of ALJs.

\section{ARGUMENT}

I. THE METHOD OF APPOINTING ALJS AND THE STATUTORY LIMITS ON MANAGEMENT AND REMOVAL OF ALJS HAS A RICH HISTORY.

A. CONGRESS DEVOTED MUCH OF THE 1930s AND 1940s TO DESIGNING A STRUCTURE IN WHICH ALJs HAVE AN APPROPRIATE DEGREE OF DECISIONAL INDEPENDENCE.

During the 1930s and 1940s, Congress devoted a great deal of time and effort to crafting legislation to govern actions taken by federal agencies. After fifteen years of debates and studies, Congress unanimously enacted the Administrative Procedure Act of 1946 (APA). See George Shepherd, Fierce Compromise: The Administrative Procedure Act Emerges from New Deal Politics, 90 N.W. U. L. Rev. 1557 (1996).

One of the core issues that Congress resolved when it enacted the APA was the status of 
the hearing examiners who were authorized to preside over oral evidentiary hearings in adjudications in the common situation in which the head of an agency did not personally preside. That issue was challenging because Congress sought to accomplish two potentially competing goals.

Members of Congress had received many complaints that the hearing examiners who presided in agency hearings prior to enactment of the APA were biased in favor of the agency and against the private parties who participated in those hearings. See Ramspeck v. Federal Trial Examiners Conference, 345 U.S. 128, 131-132 (1953). Congress responded to that concern by conferring on the new hearing examiners who would preside after enactment of the APA some degree of independence from the agencies for which they worked. Id. at 132-134.

Congress also wanted to further the potentially conflicting goal of ensuring that the agencies themselves would retain control of policy decisions in implementing their statutory directions. Congress recognized that hearing examiners who were sufficiently independent of the agency that employed them to reduce concerns of bias had the potential to usurp some of the policymaking power Congress had conferred on their agencies. Congress responded by including in the APA provisions that ensure that agencies retain the ability to make all of the policy decisions that might be raised in an adjudication in which a hearing examiner presides. See Paul Verkuil et al., The Federal Administrative Judiciary, Admin. Conf. of the United States, Recommendations and Reports, Vol. II, 770, 801-802 (1992). 
During its fifteen years of deliberation about what became the APA, Congress considered many potential ways of reconciling the tension between those two potentially conflicting goals. Congress eventually settled on a combination of statutory provisions that are designed to further both goals simultaneously. The APA includes provisions that are designed to confer a degree of independence on hearing examiners by regulating the agency processes of hiring, managing, and removing hearing examiners. But it also includes a provision that ensures that agencies retain complete control of the policy implications of adjudicatory hearings by conferring on the agency the authority to substitute the agency's decision for the initial decision of the hearing examiner. Except for some changes in terminology and compensation, Congress has not made material changes in those provisions since Congress enacted them in 1946.

In the APA, Congress gave agencies the power to appoint hearing examiners, 5 U.S.C. $\S$ 3105 , but it coupled that power with the power of the Civil Service Commission (the "Commission") to determine who is qualified to be a hearing examiner, 5 U.S.C. $\S 5372$. The Commission implemented a merit-based system for determining eligibility to be a hearing examiner, and the agencies appointed hearing examiners from the list of applicants that the Commission determined to be eligible. As a result, although ALJs usually work for a single agency, they become eligible to be ALJs through a process overseen by the Commission.

In 1972, the Commission changed the name of hearing examiners to administrative law judges (ALJs). Change of Title to Administrative Law 
Judge, 37 Fed. Reg. 16,787 (Aug. 19, 1972). In 1978, Congress ratified that decision by statute and renamed the Civil Service Commission the Office of Personnel Management (OPM). Pub. L. No. 95-251, 92 Stat. 183 (1978). (In the remainder of this brief we will use the terms hearing examiner and ALJ interchangeably.)

The vast majority of ALJs, 1,655 out of 1,926, work for the Social Security Administration (SSA). Because of frequent significant increases in its caseload, SSA often needs to hire large numbers of new ALJs. When SSA needs to hire more ALJs than the number of applicants that OPM has determined to be qualified to be ALJs, SSA asks OPM to reopen the process of determining who is eligible to be an ALJ. OPM responds to SSA's need by reopening the eligibility determination process. Through that process, OPM creates a new list of applicants eligible to be ALJs that is long enough to allow SSA to hire the number of new ALJs it needs to adjudicate the constantly increasing number of contested cases in which someone claims to be entitled to social security disability benefits. Agencies like the SEC routinely hire ALJs who have previously worked for SSA. Thus, the initial appointment of an ALJ is usually made by SSA from the list of eligible applicants created by OPM. Other agencies then choose ALJs from the large population of ALJs who work for SSA.

Congress also limited agency power to manage hearing examiners in several ways that are designed to confer a degree of independence on them, thereby protecting the rights of the regulated entities involved in adjudications. Congress's goal was to reduce the risk of pro-agency bias in the 
process of presiding in a hearing, checking agencies' power by precluding them from using managerial tools as means of inducing hearing examiners to conduct adjudicatory hearings in ways that favor the agency and disfavor the private parties who participate in the hearings. Thus, the employing agency cannot discipline a hearing examiner, 5 U.S.C. $\S 7521$; cannot determine the compensation of a hearing examiner, 5 U.S.C. $\S$ 5372; cannot assign a case to a hearing examiner except in rotation, 5 U.S.C. $\S 3105$; cannot assign a hearing examiner any duties that are inconsistent with the duties and responsibilities of a hearing examiner, 5 U.S.C. $\S 3105$; and cannot subject a hearing examiner to supervision or direction by any agency employee who engages in "the performance of investigative or prosecuting functions for an agency." 5 U.S.C. § 554(d)(2).

Finally, a disciplinary action can be taken against an ALJ "only for good cause established and determined by the Merit Systems Protection Board (MSPB) on the record after opportunity for hearing before the Board." 5 U.S.C. § 7521. Thus, although the SEC can initiate a proceeding against an ALJ, only the independent MSPB can impose any form of discipline against him or her.

At the same time that Congress protected the integrity of the hearing process by conferring a degree of independence on hearing examiners, Congress ensured that agencies retained complete control over the legal basis and policy content of any decision in an adjudication. Congress accomplished that goal by providing that a hearing examiner can make only an initial decision and that the agency has complete discretion to replace 
it: "On appeal from or review of the initial decision, the agency has all the powers which it would have in making the initial decision." 5 U.S.C. § 557(b). This Court has reinforced that congressional decision by holding that the initial decision qualifies only as part of the record on which the court must base its review. Universal Camera $v$. NLRB, 340 U.S. 474, 493-497 (1951).

\section{B. THIS COURT ISSUED A SERIES OF DECISIONS IN THE 1950s IN WHICH IT ENDORSED THE LEGAL REGIME GOVERNING ALJS THAT CONGRESS CREATED.}

Shortly after Congress enacted the APA, this Court issued a series of decisions regarding the qualified independence of hearing examiners in which it praised the APA and urged Congress to use it as a model for all agency decision-making. In Ramspeck v. Federal Trial Examiners Conference, 345 U.S. 128 (1953), the Court upheld the initial rules issued by the Civil Service Commission to govern the compensation and tenure of hearing examiners, and the rules governing assignment of cases to hearing examiners, over an objection by an association of hearing examiners that the rules were not adequately protective of the independent status of hearing examiners that the APA was enacted to protect.

The six-Justice majority described the reasons Congress conferred qualified independence on hearing examiners in the APA: "Many

complaints were voiced against the actions of hearing examiners, it being charged that they were 
mere tools of the agency concerned and subservient to the agency heads in making their proposed findings of fact and recommendations." Id. at 131 . The majority described studies that supported the complaints of bias and that urged Congress to make hearing examiners "partially independent of the agency by which they were employed." Id. at 131. The majority then described the congressional deliberations about the best ways of accomplishing that agreed-upon goal, and described with apparent approval the treatment of hearing examiners in the APA: "Several proposals were considered, and in the final bill Congress provided that hearing examiners should be given independence and tenure in the existing Civil Service system." Id. at 131-32.

The majority's description of the APA's treatment of hearing examiners and its characterization of the status of hearing examiners left no doubt that the majority understood and approved of the congressional decision to confer qualified independence on hearing examiners:

Congress intended to make hearing examiners 'a special class of semiindependent subordinate hearing officers' by vesting control of their compensation, promotion and tenure in the Civil Service Commission to a much greater extent than in the case of other federal employees.

Id. at 132. The majority upheld the Civil Service rules based on its conclusion that the rules were consistent with congressional intent: 
The position of hearing examiner is not a constitutionally protected position. It is a creature of congressional enactment. The respondents have no vested right to positions as examiners. They hold their posts by such tenure as Congress sees fit to give them. Their positions may be regulated completely by Congress, or Congress may delegate the exercise of its regulatory power, under proper standards, to the Civil Service Commission, which it has done in his case.

Id. at 133 .

The three dissenting Justices also implicitly approved of the congressional decision to confer qualified independence on hearing examiners. However, they would have held the rules invalid because of their belief that the rules should have gone even further in conferring qualified independence on hearing examiners:

The Administrative Procedure Act was designed to give trial examiners in the various administrative agencies a new status of freedom from agency control. Henceforth they were to be 'very nearly the equivalent of judges even though operating within the Federal system of administrative justice.' Agencies were stripped of power to remove examiners working with them. Henceforth removal could be effected only after hearings by the Civil Service Commission. That same Commission was empowered to prescribe an examiner's 
compensation independently of recommendations or ratings by the agency in which the examiner worked. And to deprive regulatory agencies of all power to pick particular examiners for particular cases, § 11 of the Act commanded that examiners be 'assigned to cases in rotation so far as practicable ***.' I agree with the District Court and the Court of Appeals that the regulations here sustained go a long way toward frustrating the purposes of Congress to give examiners independence.

Id. at 144 (citation omitted) (Black, J., dissenting).

The Court was even more forceful in its approval of, and praise for, the congressional decision to confer qualified independence on hearing examiners in Wong Yang Sung $v$. McGrath, 339 U.S. 33 (1950). The question before the Court was whether the APA provisions applicable to hearing examiners applied to deportation proceedings. The Court held that they did even though no statute explicitly made the APA applicable to those hearings.

The Court began by describing the widespread complaints of bias that led to the enactment of the APA and to its treatment of hearing examiners as independent of the agencies at which they preside. It also cited to the many studies that had substantiated those complaints and that had urged statutory changes to reduce the pro-agency bias. It then described the years of study and deliberation that led to enactment of the 
APA by unanimous votes in both Houses of Congress. Id. at 37-45. The Court summarized the process through which the APA was enacted: "The Act thus represents a long period of study and strife; it settles long-continued and hard-fought contentions, and enacts a formula upon which opposing social and political forces have come to rest." Id. at 40 .

The Court then compared the unfair and biased hearing that the government had provided in the case before the Court with the hearing before an impartial hearing examiner that the APA requires. Id. at 45-47. The Court even suggested that the Constitution might compel an agency to use the APA hearing procedures:

The constitutional requirement of procedural due process of law derives from the same source as Congress' power to legislate and, where applicable, permeates every valid enactment of that body. . . .

We would hardly attribute to Congress a purpose to be less scrupulous about the fairness of a hearing necessitated by the Constitution than one granted by it as a matter of expediency.

Indeed, to so construe the Immigration Act might again bring it into constitutional jeopardy. When the Constitution requires a hearing, it requires a fair one, one before a tribunal which meets at least currently 
prevailing standards of impartiality.

Id. at 49-50.

The Court concluded that the APA represented an effort by Congress to set forth the "currently prevailing standards of impartiality" and thereby to codify the minimum requirements of due process. Id. at 50. Based on that conclusion, the Court held that the provisions in the APA relating to hearing examiners applied to deportation proceedings. Id. at 51. In later cases, the Court relied on the reasoning in Wong Yang Sung as the basis to hold that the APA applies to hearings under the Interstate Commerce Act, Riss \& Co. v. U.S., 341 U.S. 907 (1951), and to Post Office fraud hearings, Cates v. Haderlein, 342 U.S. 804 (1952).

Admittedly, the Court eventually retreated from its suggestion that the APA codified due process when Congress explicitly rejected that interpretation of the Act in the process of enacting a deportation statute that authorized hearings that fell short of the procedural safeguards reflected in the APA. Marcello v. Bonds, 349 U.S. 302 (1955). But the Court never retreated from its belief that the APA adjudication provisions created a model of fairness by which all other agency adjudicatory procedures should be judged. Indeed, the Court upheld the procedures Congress authorized in deportation proceedings largely because it believed that Congress was "drawing liberally on the analogous provisions of the Administrative Procedure Act and adapting them to the 
deportation process.” Id. at 310.

\section{ANY CHANGE IN THE STATUS OF ALJS SHOULD BE CONSISTENT WITH THE OVERRIDING GOAL OF MINIMIZING THE RISK OF PRO-AGENCY BIAS.}

There are 1,931 ALJs who preside in adjudicatory hearings at present. Five are employees of the SEC. The other 1,926 preside in adjudicatory hearings conducted by 30 other agencies. $^{2}$ If this Court holds that ALJs are inferior officers, agencies and courts would then have to decide whether to acquiesce in agencyproposed methods of rehearing those millions of adjudicatory disputes, including those by the thousands of AJs whose rulings would be subject to the same challenge brought here. Even assuming some agencies could remedy the Appointments Clause deficiency in a manner similar to the SEC's approach, broader considerations related to ensuring ALJs' independence should not be overlooked.

The case before the Court is one of the many cases that were triggered by the SEC's use of the discretion Congress conferred on the agency to pursue some types of enforcement actions in adjudications before ALJs, rather than federal district judges. Professor Urska Velikonja has provided a detailed description of the manner in

2 See U.S. OPM, ALJs by Agency (Mar. 2017), https://www.opm.gov/services-for-agencies/adminstrativelaw-judges/\#url=ALJs-by-Agency. 
which section 929P(a) of the Dodd-Frank Wall Street Reform and Consumer Protection Act, Pub. L. No. 111-203, §929P(a), 124 Stat. 1376, 1862 (2010), enabled the SEC to make greater use of ALJs in some types of enforcement cases and led to the many cases in which parties who lost in those cases sought review based on alleged constitutional flaws in the appointment of the ALJs who presided in those cases. Urska Velikonja, Are the SEC's Administrative Law Judges Biased? An Empirical Investigation, 92 Wash. L. Rev. 315, 317-24 (2017).

In each of those cases, the SEC engaged in independent de novo review of the ALJ's decision and concluded that the defendant had violated securities laws, and it imposed sanctions on the defendant that included civil penalties. In each case, the party that was the subject of the sanctions sought judicial review of the SEC action and argued, inter alia, that the action was invalid because the ALJ was an inferior officer who had not been appointed in a manner consistent with the Appointments Clause.

In some of the cases, the party that was subject to the sanctions also argued that the SEC action was invalid because the for-cause limit on the SEC's ability to remove an ALJ violates the Vesting Clause and the Take Care Clause, as this Court interpreted those Clauses in Free Enterprise Fund v. Public Company Accounting Oversight Board, 561 U.S. 477 (2010). Velikonja, 92 Wash. L. Rev. at 328-30. The implicit, and in some cases explicit, allegation that ALJs are biased against the private party underlies the Appointments 
Clause claims in these cases, but the private parties do not explain why they believe there is a causal relationship between the method of appointment and the presence or absence of a proagency bias.

The claims that SEC ALJs are biased in favor of the agency echo the widespread claims of bias that provided the impetus for Congress's decision to enact the APA. That statute reduced significantly the potential for ALJ bias in the process of presiding over agency adjudications. Ironically, the claims of bias spawned by the SEC's decision to bring some enforcement actions before ALJs, rather than federal district judges, have been coupled with the argument that SEC ALJs should be appointed by the agencies where they preside and should be removable at will by the agencies where they preside.

It is hard to imagine a worse fit between an alleged problem in decision-making and a proposed remedy for that problem. If this Court makes a decision that cascades into a legal regime in which agencies have greater discretion in the process of appointing ALJs and have the discretion to remove ALJs without establishing any cause for removal, it will have eliminated many of the safeguards against pro-agency bias that Congress incorporated in the APA and that this Court praised as important mechanisms to protect the due process rights of the private parties who participate in agency hearings. That, of course, would increase the risk that SEC ALJs will make decisions that reflect pro-agency bias in their roles 
as presiding officers.

A holding that SEC ALJs are inferior officers who must be appointed by heads of departments would not necessarily conflict with the congressional goal that was the basis for the safeguards of ALJ independence that Congress incorporated in the APA as long as the initial determinations of basic qualifications continued to be made by OPM. The APA authorizes agencies to appoint ALJs, and this Court has held that the SEC qualifies as a "head of department," as that term is used in the Appointments Clause. Free Enterprise Fund, 561 U.S. at 512-13. Such a holding would be consistent with the critical role that Congress assigned the OPM in determining the people who have the qualifications required to be eligible for appointment by the SEC. Congress often limits the scope of the power of appointment by qualifying it in various ways, and no court has ever held that such a limit violates the Appointments Clause. ${ }^{3}$

But the potential removal ramifications of this series of SEC challenges cannot be ignored, because they are critical to the broader

${ }^{3}$ In FEC v. NRA Political Victory Fund, 6 F. 3d 821, 824-25 (D.C. Cir. 1993), the D.C. Circuit held that the constitutional validity of the common statutory restriction on the President's power to appoint no more than a bare majority of the members of a multi-member agency is not justiciable. This Court dismissed the petition for writ of certiorari that was filed in the case on the basis that the FEC lacks the power to represent the United States in the Supreme Court. FEC v. NRA Political Victory Fund, 513 U.S. 88, 90 (1994). 
considerations of neutrality underlying the ALJ provisions of the APA. Were this Court to hold ALJs to be inferior officers without using cautiously cabined analysis, a later court would likely conclude that the statutory for-cause limit on an agency's power to remove an ALJ violates separation of powers. Such a holding would have a devastating effect on the decisional independence of ALJs. As this Court has recognized, the power to remove a government official creates a "here and now subservience" between the government official and the individual or institution that has the power to remove the official. Bowsher v. Synar, 478 U.S. 714, 720, 730 (1986). That subservient relationship is particularly powerful when the entity that has the power to remove the official is not required to state a cause for removing the official. If the SEC could remove an ALJ without having shown good cause for removal, the risk that SEC ALJs would behave in a manner that is biased in favor of the agency would increase dramatically.

\section{CONCLUSION}

Regardless of the outcome of the Appointments Clause issue, the Court should resolve the issue in a manner that is respectful of the independent relationship between ALJs and the agencies that employ them that Congress created by passing the APA. 
Respectfully submitted,

RICHARD J. PIERCE, JR.

COUNSEL OF RECORD

ROBERT GLICKSMAN

EMILY HAMMOND

ALAN B. MORRISON

JONATHAN R. SIEGEL

The George

WASHINGTON

UNIVERSITY LAW

SCHOOL 2000 H STREET NW

Washington, DC 20052

(703) 304-1623

rpierce@law.gwu.edu

February 28, 2018 
Add. 1

\title{
ADDENDUM: LIST OF PARTICPATING SCHOLARS
}

\author{
William D. Araiza \\ Brooklyn Law School \\ Michael Asimow \\ Stanford Law School \\ Bernard W. Bell \\ Rutgers Law School \\ Marshall Breger \\ Columbus School of Law \\ The Catholic University of America \\ Bryan T. Camp \\ Texas Tech University School of Law \\ Joel B. Eisen \\ University of Richmond School of Law \\ Samuel Estreicher \\ NYU School of Law \\ Steve C. Gold \\ Rutgers Law School \\ Natalie Gomez-Velez \\ CUNY School of Law \\ Mark H. Grunewald \\ Washington and Lee University School of Law
}


Add. 2

Emily Hammond

George Washington University School of Law

William Funk

Lewis \& Clark Law School

Robert Glicksman

George Washington University School of Law

Jeffrey Lubbers

American University, Washington College of Law

Jerry Mashaw

Yale Law School

Joel A. Mintz

Nov Southeastern University College of Law

Alan B. Morrison

George Washington University School of Law

Richard J. Pierce, Jr.

George Washington University School of Law

Andrew F. Popper

American University, Washington College of Law

Edward P. Richards

Louisiana State University Law Center

Michael Sant'Ambrogio

Michigan State University College of Law

Joshua I. Schwartz

George Washington University School of Law 
Add. 3

Sid Shapiro

Wake Forest University School of Law

Allen E. Shoenberger

Loyola Chicago Law School

Jonathan R. Siegel

George Washington University School of Law

Peter L. Strauss

Columbia Law School

Paul R. Verkuil

Senior Fellow and Former Chair, Administrative

Conference of the United States

Keith Werhan

Tulane Law School

Adam S. Zimmerman

Loyola Law School, Los Angeles 